\title{
DISEMINASI TEKNOLOGI PUPUK KANDANG SAPI PLUS RIZOBAKTERI PADA KELOMPOK TANI KAKAO DI KABUPATEN LIMA PULUH KOTA
}

\author{
Haliatur Rahma $^{\left.{ }^{*}\right)}$, Jumsu Trisno ${ }^{1)}$, Martinius ${ }^{1)}$, Reflin $^{1)}$, Sri Wahyuni ${ }^{2)}$, Nusyirwan $^{3)}$ \\ ${ }^{1)}$ Prodi Proteksi Tanaman Fakultas Pertanian Universitas Andalas \\ ${ }^{2)}$ Prodi Penyuluhan Fakultas Pertanian Universitas Andalas \\ ${ }^{3)}$ BPTP Sukarami, Sumatera Barat \\ ${ }^{*}$ Email : haliaturrahma@agr.unand.ac.id
}

\begin{abstract}
ABSTRAK
Kegiatan diseminasi teknologi pupuk kandang sapi plus rizobakteri pada tanaman kakao dilakukan di Kecamatan Guguak dan Akabiluru Kabupaten Lima Puluh Kota yang dimulai dari bulan Maret sampai dengan November 2018. Kegiatan ini bertujuan untuk mengenalkan teknologi formulasi pupuk kandang plus rizobakteri pada kelompok tani kakao. Inovasi, buah lobek, maju sejahtera dan aroma menggunakan metode penyuluhan. Pentingny kegiatan ini dilakukan disebabkan oleh tingginya kejadian dan keparahan penyakit VSD di Kecamatan Guguak dan Akabiluru Kabuparten Limapuluh Kota yang mencapai 86,60\%. Untuk itu, diperlukan teknologi pengendalian yang mudah dibuat, murah dan bahan baku yang mudah diperoleh disekitar petani. Penggunaan air kelapa merupakan salah satu perbanyakan bakteri Serratia maresescens dan Pseudomonas fluorescens yang nanti akan diformulasi dengan pupuk kandang. Kegiatan ini meliputi: pemantauan tingkat serangan OPT dilahan kelompok tani kakao, kemudian dilanjutkan dengan penyuluhan, pelatihan, dan evaluasi hasil kegiatan. Dari hasil kegiatan bahwa kegiatan ini mampu meningkatkan pengetahuan petani terhadap penggunaan biofertilizer yang berasal dari bakteri yang diformulasikan dengan air kelapa dan pupuk kandang, sehingga penggunaan formulasi ini mampu mengurangi biaya penggunaan pupuk kimia yang memiliki harga yang mahal.
\end{abstract}

Kata Kunci: biofertilizer, serratia marsescens, pseudomoans fluorescens, oncobasidium theobromae

\section{Dissemination of Technology Cow Manure Plus Rhizobacteria to Cocoa Farmer Group at Sub District Guguak Lima Puluh Kota}

\begin{abstract}
Dissemination Cow manure technology plus rhizobacteria in cocoa plants is carried out in the Districts of Guguak and Akabiluru in Lima Puluh Kota from March to November 2018. The Community Service activities are carried out with the aim of introducing manure fertilizer formulation technology plus rhizobacteria to cocoa farmers Inovasi, Buah Lobek, Maju Sejahtera dan Aroma using extension methods. This counseling was motivated by the high incidence and severity of VSD disease in Guguak and Akabiluru Subdistrict Limapuluh Kota District and reaching 86.60\%. And control technology is needed that is easy to make, cheap and raw materials that are easily obtained around farmers, namely the use of coconut water as a multiplication of Serratia maresescens and Pseudomonas fluorescens bacteria which will be formulated in cow manure. These activities include: Monitoring the level of pest attacks on the land of the cocoa farmer group, counseling, training, and evaluating the results of activities. This dedication activity can increase farmers' knowledge of the use of biofertilizers from bacterial groups formulated with coconut water and cow manure, so that reduce the cost of using chemical fertilizers that have expensive prices.
\end{abstract}

Keyword: biofertilizer, serratia marsescens, pseudomoans fluorescens,oncobasidium theobromae 


\section{PENDAHULUAN}

Provinsi Sumatera Barat merupakan salah satu daerah sentra produksi kakao (Theobroma cacao L.) di Indonesia. Daerah sentra produksi kakao Sumatera Barat tersebar di 19 Kabupaten/Kota diantaranya: Kabupaten Pasaman, Padang Pariaman, Pasaman Barat, Agam, Kota Sawahlunto, dan Lima Puluh Kota (Badan Perencanaan Pembangunan Daerah dan Badan Pusat Statistik, 2015). Kabupaten Limapuluh Kota merupakan salah satu sentra produksi tanaman kakao yang sangat potensian. Mengingat besarnya potensi Kabupaten Limapuluh Kota terhadap produksi kakao, pemerintah telah membantu sebanyak 300 ribu batang kakao yang dibagikan untuk 30 kelompok tani yang ada di kecamatan- kecamatan di Kab. Lima puluh Kota masing-masing 10.000. Saat ini lebih 200 kelompok tani kakao yang memiliki luas lahan 8.000 hektar.

Kecamatan Guguak merupakan salah satu sentra produksi kakao di Kabupaten Lima Puluh Kota Daerah ini mempunyai potensi yang tinggi terhadap pengembangan kakao di Sumatera Barat, karena masih terdapatnya lahan tidur dan lahan di bawah tanaman kelapa dan dapat juga ditumpangsarikan dengan tanaman perkebunan lainnya. Namun karena perkebunan kakao lebih banyak di kelola oleh rakyat yang memiliki pengetahuan yang minim terhadap budidaya kakao, sehingga banyak lahan kakao yang tidak terpelihara dengan baik bahkan dibiarkan tumbuh rapat tanpa dilakukan pemangkasan, sehingga banyak lahan kakao yang telah menjadi "hutan kakao", untuk lahan yang tidak terpelihara dengan baik. Hal ini menjadi pemicu tingginya tingkat serangan Organisme Pengganggu Tanaman (OPT) baik dari kelompok hama maupun patogen.

Penyakit VSD merupakan salah satu kendala utama dalam budi daya kakao karena perkembangan dan penyebarannya yang cepat. Penyakit ini merupakan penyakit baru pada tanaman kakao di Sumatera Barat dimana kejadian penyakit mencapai $100 \%$ dengan keparahan 24.29-44.71\% (Trisno et al., 2016), data mengenai dampak ekonomi dari serangan penyakit ini masih belum ada dikemukakan.

Hasil survei dan wawancara dengan petani di Kabupaten Limapuluh Kota, banyak kebun kakao yang sudah dimusnahkan dan diganti dengan tanaman lain, karena penyakit VSD yang menyebabkan daun-daun gugur, tanaman gundul dan tidak lagi menghasilkan. Harni dan Baharuddin (2014) menambahkan penyakit VSD sulit dikendalikan karena berada dalam jaringan pembuluh. Oleh sebab itu perlu dicarikan teknologi yang memanfaatkan potensi alami yang dimungkinkan dapat mengendalikannya. Salah satu teknologi alternatif yang dikembangkan adalah menggunakan mikroba bermanfaat sebagai salah satu agens pengendalian hayati (biological control agent) dalam pengendalian hama dan penyakit tanaman.

Pemanfaatan bakteri perakaran (rizobakteri) untuk meningkatkan ketahanan tanaman sudah banyak dilaporkan seperti penggunaan $P$. flourescens LPK1.9, $B$. Subtilis TD1.3 dan B. Subtilis TD1.8 untuk tanaman cabai terhadap penyakit virus daun kuning keriting dengan penekanan perkembangan penyakit sampai 75\% (Trisno et al, 2013), Serratia marsescens dan Basillus sp untuk tanaman jagung terhadap penyakit layu pembuluh (stewart) (Rahma et al. 2014). Untuk mempertahankan kondisi pertumbuhan rizobakteri dan kemudahan aplikasi di lapangan, maka rizobakteri perlu di formulasi dengan berbagai bahan organic berupa limbah air kelapa serta pupuk kandang. 
Pemanfaatan bahan organik air kelapa dan pupuk kandang sebagai bahan formulasi untuk agens hayati selain mudah diperoleh, biaya murah, aman bagi lingkungan dan kesehatan dan dapat di produksi ditingkat petani. Menurut Rakhmadi et al., (2018), Penggunaan pupuk kandang sebagai bahan dasar pembuatan kompos memerlukan fermentasi atau dekomposisi dalam pembuatannya. Secara alami membutuhkan waktu yang sangat lama untuk prosesnya.Untuk mempercepat prosesnya biasanya masyarakat menambahkan stardec/EM4 dalam prosesnya.EM4 adalah bakteri pengurai bahan organik yang khusus digunakan dalam pembuatan kompos. Karena EM4 atau Stardec membutuhkan dana yang besar dalam pembuatan pupuk maka fungsi EM4 ini dapat digantikan oleh MOL rebung. Dalam penelitian ini proses fermentasi pupuk kandang sapi dilakukan dengan menggunakan 2 isolat bakteri Serratia marsescens AR1 dan Pseudomonas fluorescens LPK1-9 yang telah di perbanyak menggunakan air kelapa.

Tujuan kegiatan pengabdian ini adalah untuk memasyarakatkan penggunaan formula pupuk kandang sapi yang difermentasi dengan rizobakteri (Pukan-plus $\mathrm{Rb}$ ) untuk pengendalian penyakit VSD tanaman Kakao di tingkat petani.

\section{METODE}

Kegiatan Diseminasi ini dilaksanakan dari Bulan Maret sampai November 2018, menggunakan metode SL-PHT pada kelompok petani kakao Inovasi, Buah Lobek di Nagari Sungai Talang, Kelompok Tani Maju Sejahtera Nagari Tujuh Koto Talago di Kec. Guguak, dan Kelompok Tani Aroma dari Nagari Sungai Balantiak Kecamatan Akabiluru Kabupaten Lima Puluh Kota. Sumatera Barat. Kegiatan ini meliputi Sosialisasi, pelatihan dan aplikasi Pukan-Plus Rizobakteri pada tanaman kakao, Supervisi serta Evaluasi.

1. Sosialisasi program ke calon kelompok petani kakao

Kegiatan ini merupakan kegiatan awal aktivitas diseminasi yang akan dilakukan oleh Tim peneliti. Tujuan kegiatan ini adalah untuk memperkenalkan sekilas program diseminasi yang akan dilaksanakan. Selain untuk memperkenalkan program, juga untuk melihat sejauh mana minat atau animo petani target terhadap program yang akan dilaksanakan.

Pemilihan dan penetapan kelompok ditentukan berdasarkan hasil sosialisasi. Pada kegiatan ini juga dilakukan sebentuk perjanjian/ komitmen tertulis antara Tim Peneliti (pembawa program) dengan kelompok tani pelaksanan program. Perjanjian ini bertujuan untuk mengawal program sesuai dengan rencana yang telah ditetapkan.

\section{Peningkatan Kapasitas Kelompok}

\subsection{Penyuluhan}

Penyuluhan dilakukan di Saung milik salah satu petani kakao di Nagari Sungai Talang dan lahan Demplot masing-masing kelompok tani yang dilaksanakan selama dua hari dengan muatan materi teori dan praktek. Pemateri berasal dari dosen/peneliti, Dinas Pertanian Kabupaten Limapuluh Kota dan petani pakar. Dengan materi teori: a. Organisme Pengganggu Tumbuhan (OPT) tanaman kakao, b. Penyakit VSD pada tanaman kakao, c. Pengendalian penyakit VSD/penyakit kakao dan Pengendalian hayati penyakit tanaman menggunakan mikroorganisme. 


\subsection{Praktek}

Praktek dilakukan pada masing-masing lahan demplot kelompok tani, dengan materi praktek adalah: a. Teknik diagnosa, deteksi dan pengendalian OPT khususnya penyakit VSD di lapang, b. Teknik pembuatan formulasi Pukan-Plus Rizobakteri. Bahan dan alat yang dibutuhkan dalam praktek adalah: Isolat rizobakteri Serratia marsescens AR1 dan Pseudomonas fluorescens LPK1-9, pupuk kandang sapi, air kelapa, gula, gallon air mineral, aerator akuarium berserta selang, terpal $6 \times 8 \mathrm{~m}$, gunting tanaman dan lem.

Pembuatan Pukan-Plus Rizobakteri dilakukan dengan cara: isolate rizobakteri koleksi Laboratorium Pengendalian Hayati yang telah dibiakkan pada media LB di perbanyak menggunakan air kelapa $+10 \%$ gula menggunakan biofermentor sederhana dengan mesin penggerak selama 10 hari. Prinsip kerja alat ini (aerator merek Resun LP40) ialah memberikan udara (melalui aerator) ke dalam galon kemudian udara yang keluar selang menuju botol yang berisi air sebagai kontrol jika terjadi kebocoran. (Pada saat pelatihan, suspense bakteri dalam telah disiapkan oleh peneliti).

Suspensi bakteri yang telah disiapkan oleh tim peneliti dicampurkan dengan pupuk kandang dengan perbandingan 1 : 5 (sebelum dicampur dengan pupuk kandang suspense rizobakteri ditambahkan air dengan perbandingan 1:4. Setelah suspensi bakteri dan pupuk tercampur rata, pupuk dibungkus dengan terpal (kondisi anaerob) dan dibiarkan selama 1 bulan. Setelah masa inkubasi, pupuk kandang hasil fermentasi (Pukan-Plus Rizobakteri) di timbang $15 \mathrm{~kg} /$ pohon dan siap di aplikasi di sekitar perakaran tanaman kakao.

Pada saat praktek petani langsung melakukan bagaimana menyiapkan suspense bakteri yang nanti akan di fermentasikan dengan pupuk kandang sapi (Pukan-Plus Rizobakteri), dan diinkubasi selama satu bulan dan siap untuk di aplikasi ke tanaman kakao. Aplikasi Pukan-Plus Rizobakteri sebanyak 15 kg/pohon (Rahma et al., 2017). Praktek pembuatan Pukan-Plus Rizobakteri dilakukan 3 kali selama periode Diseminasi yang dilakukan oleh masing-masing kelompok tani.

\subsection{Monitoring dan Evaluasi}

Monitoring dilakukan setiap bulan, untuk memantau keberhasilan adopsi inovasi oleh petani dalam baik dalam pembuatan dan aplikasi Pukan-Plus Rizobakteri serta perkembangan penyakit VSD yang telah di aplikasi dengan Pukan-Plus Rizobakteri.

\section{HASIL DAN PEMBAHASAN}

1. Sosialisasi program ke calon kelompok petani kakao

Kegiatan ini merupakan kegiatan awal semua aktivitas pengabdian yang dilakukan oleh Tim peneliti. Tujuan kegiatan ini adalah untuk memperkenalkan sekilas program yang akan dilaksanakan. Selain untuk memperkenalkan program, juga untuk melihat sejauh mana minat atau animo petani target terhadap program yang akan dilaksanakan. Kegiatan ini juga untuk menghindari kesan bahwa pelaksanaan kegiatan bersifat kepentingan satu pihak melainkan juga adanya keinginan dan minat petani untuk menerima teknologi yang ditawarkan sehingga di peroleh kesepakatan untuk melaksanakan inovasi. Pada kegiatan ini di undang sebanyak empat kelompok petani calon penerima diseminasi yang terdiri dari 15 orang untuk masing masing 
kelompoknya (Gambar 1). Selanjutnya, Kepala Desa dan Pemuka masyarakat di Kecamatan Guguak dan Kecamatan Talago Kabupaten Lima Puluh Kota.

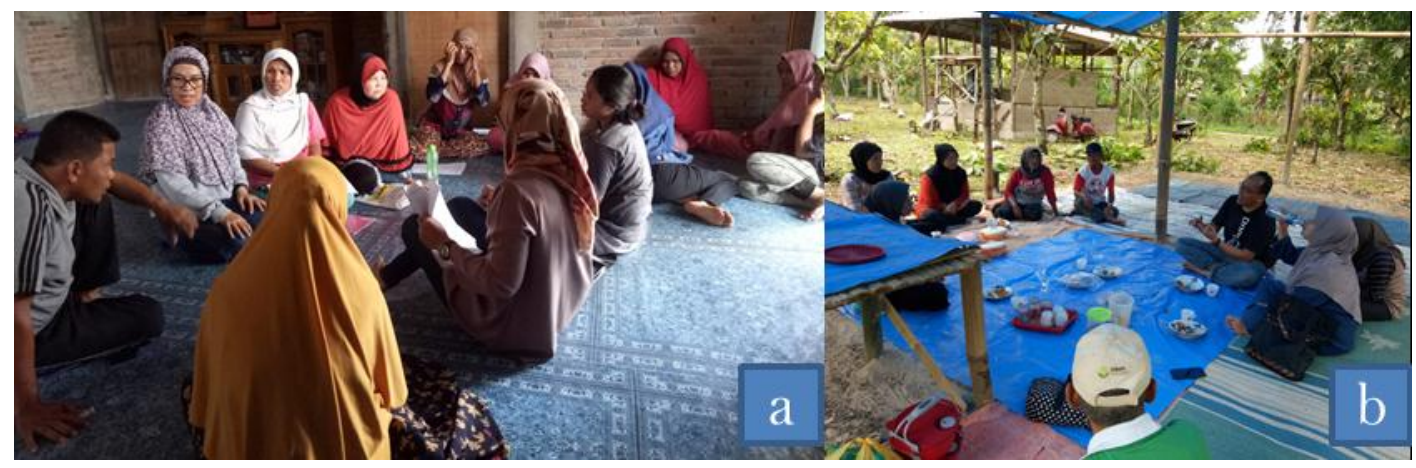

Gambar 1. Sosialisasi program kegiatan diseminasi ke petani, pemuka masyarakat, PPL, Kepala Desa: a). Di Kenagarian Sungai Talang, b). Di Kenagarian Tujuah Koto, Kabupaten Lima Puluh Kota.

Sebanyak 4 Kelompok Tani terpilih sebagai target program pengembangan paket teknologi BP3T-pupuk kandang sapi dan nano serai wangi terhadap penyakit VSD di Tingkat petani, yaitu Kelompok Tani Inovasi, Buah Lobek, Aroma dan Maju Sejahtera.

\section{Kelompok Tani Inovasi}

Kelompok Tani Inovasi merupakan kelompok tani kakao yang berada di nagari Sungai Talang kecamatan Guguak, Kabupaten 50 Kota. Hingga saat ini, kelompok tani Inovasi memiliki anggota sebanyak 8 orang.

\section{Kelompok Tani Buah Lobek}

Kelompok Tani Buah Lobek merupakan kelompok tani kakao yang berada di nagari Sungai Talang kecamatan Guguak, Kabupaten 50 Kota. Kelompok tani ini berdiri pada tanggal 23 Juli 2017 dengan jumlah anggota sebanyak 14 orang. Berdirinya kelompok tani ini didasari dengan melihat kondisi kebun kakao di lingkungan berdirinya kelompok sangat memprihatinkan, demikian juga dengan kondisi tanamannya. Oleh karena itu, para anggota membentuk kelompok tani Buah Lobek untuk memperbaiki tanaman kakao agar menjadi lebih baik.

\section{Kelompok Tani Aroma}

Kelompok Tani Aroma merupakan kelompok tani yang berada di nagari Sungai Balantiak, Kecamatan Akabiluru, Kabupaten 50 Kota. Kelompok Tani Aroma saat ini terdiri atas 12 orang anggota, termasuk di dalamnya pengurus inti yang terdiri atas ketua, bendahara, dan sekretaris. Sejak terbentuknya kelompok tani Aroma pada tahun 2014 silam, kegiatan usahatani kakao anggota kelompok lebih terarah, terutama karena kelompok tani ini mewajibkan sistem gotong royong dalam pengelolaan kakao anggota.

\section{Kelompok Tani Maju Sejahtera}

Kelompok tani Maju Sejahtera merupakan kelompok tani yag berada di nagari Tujuah Koto Talago Kecamatan Guguak Kabupaten 50 Kota. Kelompok tani maju sejahtera telah berdiri sejak bulan Oktober 2016 dengan anggota sebanyak 12 orang. 
Kelompok tani ini berdiri karena banyaknya anggota kelompok tani Maju Sejahtera yang mulanya tidak termasuk pada anggota kelompok tani manapun, sehingga mereka ingin membentuk kelompok baru agar mendapatkan pendidikan, pelatihan, dan pengetahuan tentang kakao. Oleh sebab itu, terbentuklah kelompok tani Maju Sejahtera.

\section{Peningkatan Kapasitas Kelompok}

\subsection{Penyuluhan}

Kegiatan ini bertujuan agar petani mampu mendeteksi penyakit VSD dan cara pengendaliannya serta mampu membuat formulasi Pukan-Plus Rizobakteri untuk meningkatkan ketahanan tanaman kakao terhadap penyakit VSD. Pelatihan dilaksanakan selama dua hari pada Minggu pertama bulan kedua kegiatan dengan materi teori dan praktek. Pemateri berasal dari dosen/peneliti dari Universitas Andalas, Dinas Pertanian Kabupaten Limapuluh Kota dan petani pakar yang sudah mendapat pengakuan secara nasional (Gambar 2). Dengan materi teori sebagai berikut:

a. Organisme Pengganggu Tumbuhan (OPT) tanaman kakao

b. Penyakit VSD pada tanaman kakao

c. Pengendalian penyakit VSD/penyakit kakao

d. Pengendalian hayati penyakit tanaman menggunakan mikroorganisme dan pestisida nabati

Sedangkan materi praktek adalah sebagai berikut:

a. Teknik diagnosa, deteksi dan pengendalian OPT khususnya penyakit VSD di lapang

b. Teknik pembuatan formulasi Pukan-Plus Rizobakteri

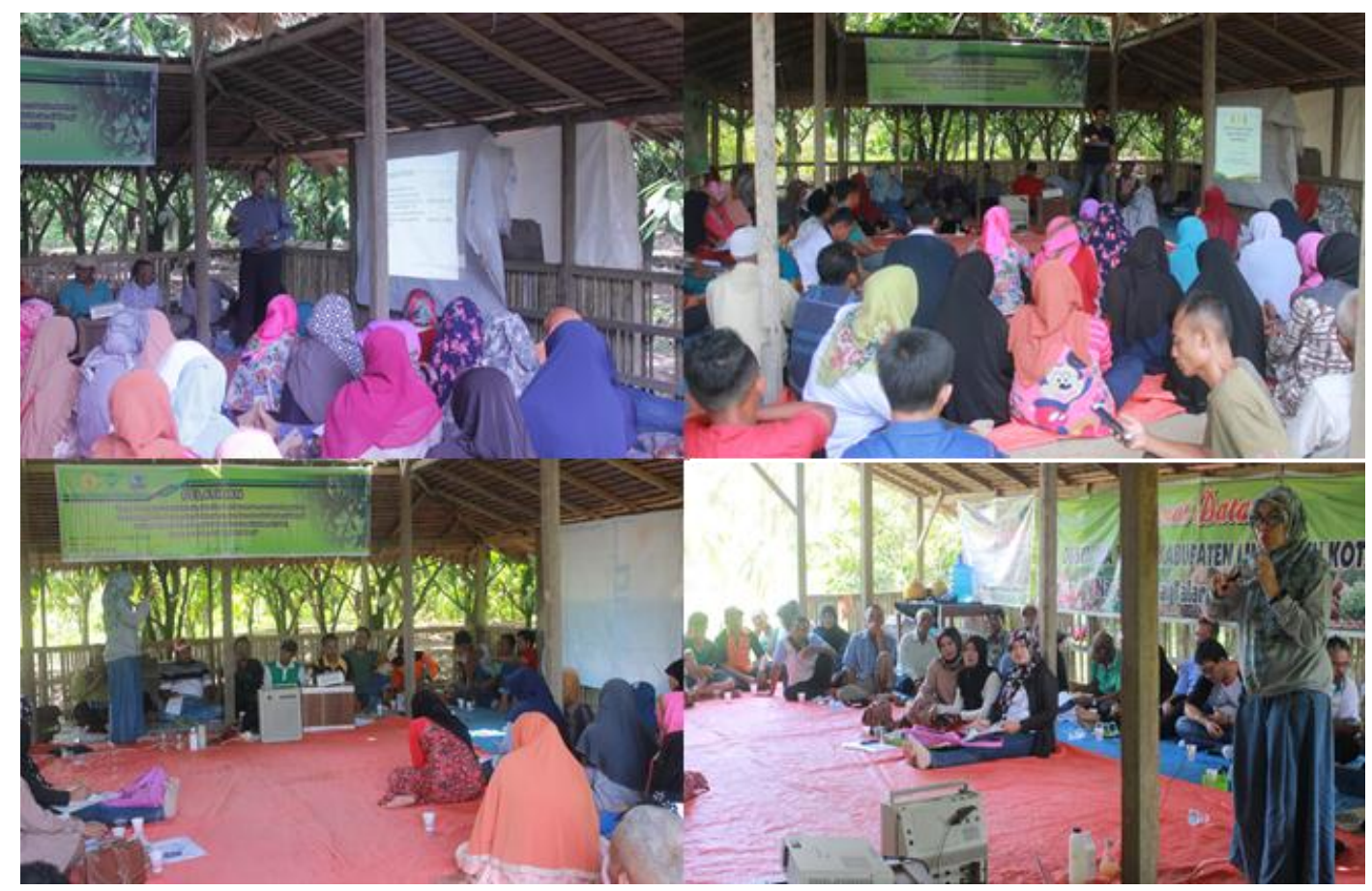

Gambar 2. Kegiatan pelatihan dan pemberian materi serta diskusi adopsi inovasi pukan-plus rizobakteri (rb) pada kelompok tani kakao untuk pengendalian penyakit vascular streak dieback (VSD) di Kecamatan Guguak Kabupaten Limapuluh Kota 
Jurnal Hilirisasi IPTEKS

Vol. 1 No. 4, Desember 2018

Website. http://hilirisasi.lppm.unand.ac.id

e-ISSN: 2621-7198 


\section{Aplikasi Perlakuan}

Aplikasi perlakuan teknologi Pukan-Plus Rizobakteri ini dilakukan pada empat demplot kelompok tani kakao di Kabupaten Lima Puluh Kota. Kegiatan ini bertujuan agar peserta mampu membuat formulasi BP3T- pupuk kandang sapi dan penerapan nano pestisida serai wangi. Masing-masing kelompok tani diberikan perlengkapan fermentor bakteri dan nano pestisida serai wangi (Gambar 4). Harapannya peserta mampu membuat teknologi tersebut secara sederhana dan mandiri. Dalam hal ini perguruan tinggi bertindak sebagai fasilitator.

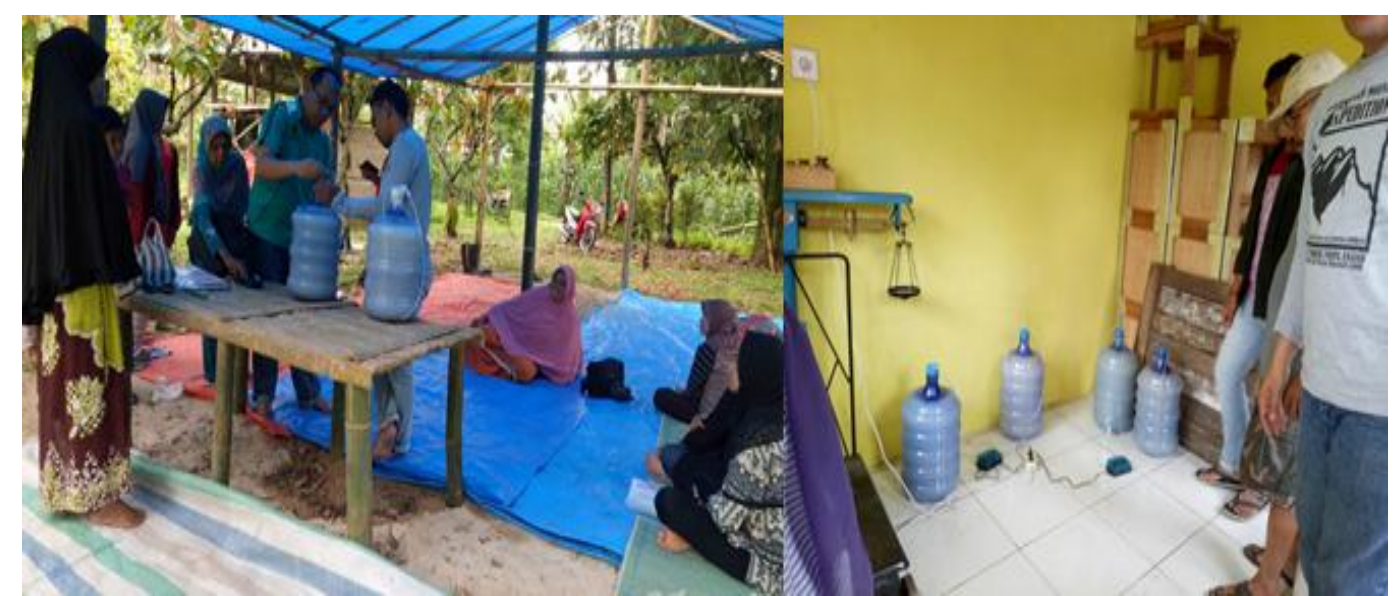

Gambar 4. Praktek pembuatan sekaligus penyerahan formulasi Rizobbakteri menggunakan air kelapa dan diinkubasi menggunakan fermentor sederhana (galon+mesin pompa, selang), ke kelompok tani.

Aplikasi formulasi Pukan-Plus Rizobakteri mampu mengurangi penggunaan pupuk dan pestisida sintetis di kalangan petani. Hasil penelitian sebelumnya didapatkan dosis terbaik dalam menekan perkembangan penyakit VSD adalah $15 \mathrm{~kg} /$ pohon. Proses pengadukan suspensi Pukan-Plus Rizobakteri dengan pupuk kandang sapi dapat dilihat pada Gambar 5.

Kegiatan penyuluhan dihadiri 40 orang, yang terdiri atas 10 orang dari masingmasing Kelompok Tani Inovasi, Buah Lobek, Aroma dan Maju Sejahtera. Selain dihadiri oleh anggota Kelompok Tani yang ditunjuk, acara penyuluhan juga dihadiri oleh pemuka masyarakat sehingga kehadiran mereka dapat menjadi mativator bagi petani untuk menerima materi penyuluhan.

Penggunaan agens hayati khususnya fromulasi Pukan-Plus Rizobakteri belum pernah dilakukan oleh keempat kelompok tani ini, sehingga ketika acara diskusi mereka sangat antusias mendengarkan pemaparan tim pengabdian. Karena mereka belum pernah menggunakan agens hayati, mereka terlihat sangat tertarik. Melalui kegiatan pelatihan ini dipaparkan juga bagaimana cara memperbanyak agens hayati Serratia marsescens dan Pseudomonas fluorescens dengan teknik yang mudah dan murah. Hal ini terlihat dari rasa keingintahuan mereka yang tinggi, sehingga pemuka masyarakat sangat berkeinginan agar kerjasama dapat berlanjut sampai mereka dapat memproduksi agens hayati secara mandiri. 


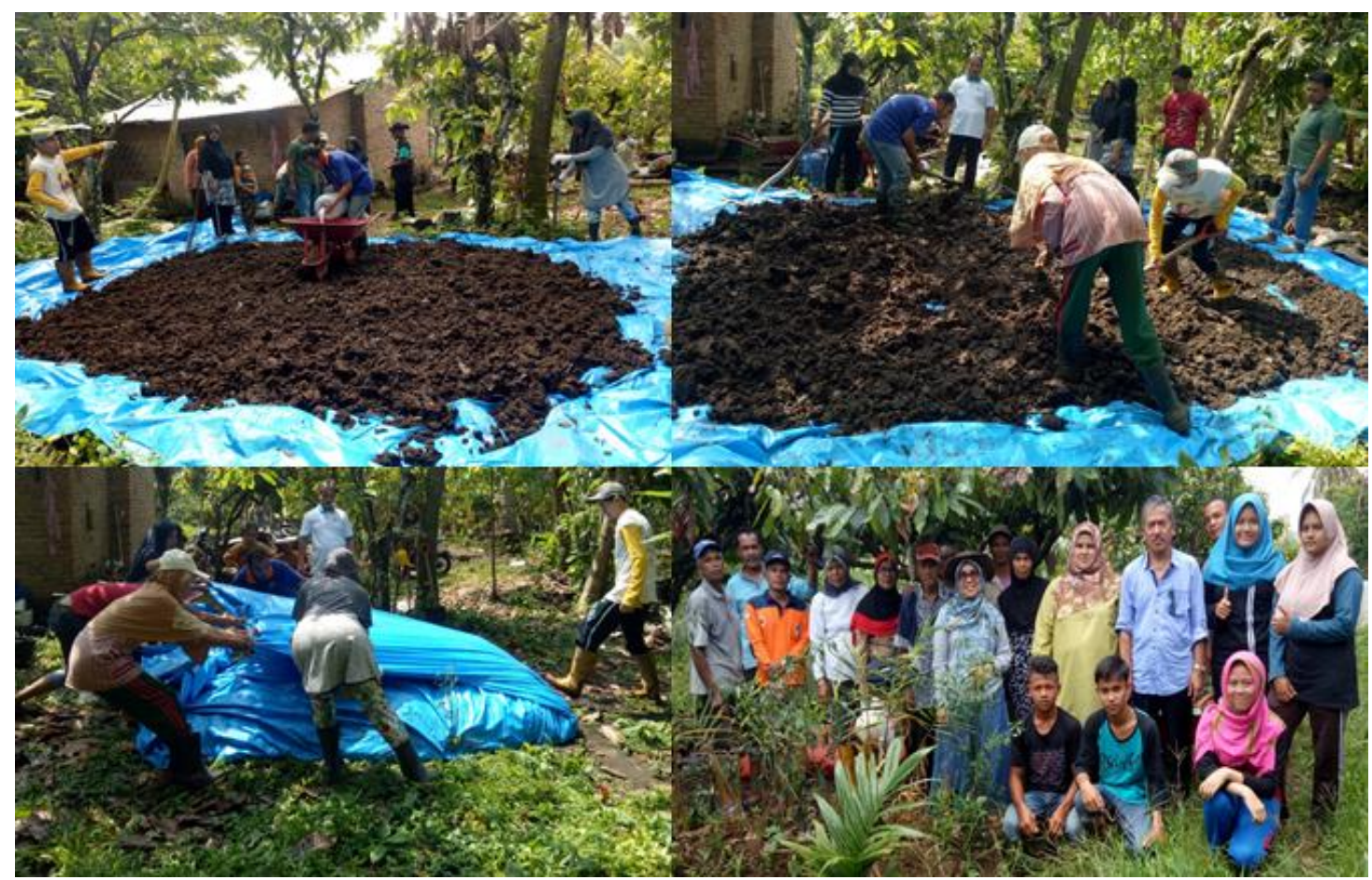

Gambar 5. Proses pengadukan suspensi rizobakteri dengan pupuk kandang sapi pada demplot percobaan.

Bakteri Serratia marcescens menghasilkan pigmen merah yang merupakan metabolit sekunder yang diketahui sebagai prodigiosin yang bersifat antibakteri, antifungal, antiprotozoal, dan anti serangga (Priyatno 2011). Sehingga diharapkan bakteri ini dapat menjadi alternatif pengendalian OPT pada tanaman kakao. Disamping itu, perbanyakan masal kedua bakteri ini juga cukup mudah dengan memanfaatkan air kelapa segar yang direbus dan ditambahkan gula, kemudian difermentasi selama 7 hari. Aplikasi bakteri ini juga bisa dilakukan pada benih serta disemprotkan pada permukaan tanaman pada saat sore hari untuk menghindari terik sinar matahari dengan aplikasi 5 ml/1L air. Pada akhir penyuluhan dilakukan penyerahan biakan masal Serratia marsescens dan Pseudomonas fluorescens (4 galon) serta pupuk kandang kepada Ketua Kelompok Tani, diharapkan penyerahan agens hayati ini merupakan langkah awal untuk pengenalan agens hayati dan akan berlanjut secara kontinyu sehingga petani memiliki kemampuan secara mandiri dalam memproduksi dan mengaplikasikan agens hayati dan kemampuan ini bisa disebarkan ke petani lain di luar kelompok tani mereka.

\section{KESIMPULAN}

Penggunaan agens hayati Pukan-Plus Rizobakteri untuk pengendalian OPT tanaman kakao belum pernah dilakukan. Adanya kegiatan pengabdian ini mampu meningkatkan pengetahuan petani terhadap penggunaan biofertilizer dari kelompok bakteri Serratia marsescens dan Pseudomonas fluorescens yang diformulasi dengan air kelapa dan pupuk kandang sapi yang gampang di peroleh di sekitar lingkungan petani, sehingga penggunaan formulasi ini mampu mengurangi biaya penggunaan pupuk kimia yang memiliki harga yang mahal. 


\section{UCAPAN TERIMA KASIH}

Pengabdian Kepada Masyarakat ini merupakan bagian dari Kerjasama Badan Penelitian dan Pengembangan Pertanian Kantor Pusat Jakarta dengan Lembaga Penelitian dan Pengabdian kepada Masyarakat. Nomor: 31.91/PL.040/H.1/02/2018.K Tanggal 12 Februari 2018. Kepada LPPM, Dekan Fakultas Pertanian Universitas Andalas, Kelompok Tani Kakao Inovasi, Buah Lobek, dan Maju Sejahtera Kenagarian Sungai Talang, Kecamatan Guguak, serta kelompok Tani Kakao Aroma Kecamatan Akabiluru Kabupaten Lima Puluh Kota serta pemuka masyarakat yang telah ikut berpatisipasi dalam pelaksanaan pengabdian masyarakat ini diucapkan terima kasih.

\section{DAFTAR PUSTAKA}

Harni, R dan Baharuddin. 2014. Kefektifan minyak cengkeh, seraiwangi dan ekstrak bawang putih terhadap penyakit Vascular streak dieback (Ceratobasidium theobromae) pada kakao. J.TIDP 1(3): 167-174

Priyatno TP. 2011. Identifikasi Entomopatogen Bakteri Merah pada Wereng Batang Coklat (Nilaparvata lugens Stal.). J. AgroBiogen 7(2):85-95. 30 September 2011. Balai Besar Penelitian dan Pengembangan Bioteknologi dan Sumberdaya Genetik Pertanian.

Rahma H, Zainal A, Sinaga MS, Surahman M, dan Giyanto. 2014. Potensi bakteri endofit dalam menekan penyakitlayu stewart (Pantoea stewartii subsp. stewartii) pada tanaman jagung. J. HPT Tropika. 14(2): 121-127.

Rahma H, Trisno J, Noveriza R, Yuliani S, Martinius, dan Reflin. 2017. Paket Teknologi Bakteri Perakaran Pemacu Pertumbuhan Tanaman Dengan Pupuk Kandang Dan Nano Pestisida Serai Wangi Untuk Pengendalian Penyakit Vsd Tanaman Kakao. Laporan Penelitian KP4S. Universitas Andalas. Padang

Rakhmadi A, Allismawita, Juliyarsi I.2018. Teknologi Pembuatankompos Kotoran Sapi Simental Dengan Penggunaan Tithonia (Thitoniadiversifolia) Dan Mol Rebung Pada Kelompok Tani Ternak. Jurnal Hilirisasi IPTEKS. 1(3) : 51-56

Trisno J, Reflin dan Martinius. 2016. Vascular Streak Dieback (VSD) Penyakit Baru Tanaman Kakao di Sumatera Barat. J. Fitopatol. Indo. In press

Trisno J, Habaza T, Jamsari dan Hidayat SH. 2013.Penapisan kemampuan isolat rizobakteri indigenus dalam meningkatkan ketahanan tanaman cabai terhadap penyakit virus daun kuning keriting. Prosiding Seminar Nasional dan Rapat tahunan dekan bidang ilmu pertanian BKS wilayah Barat. Pontianak $14-20$ Maret 2013: 889-902. 